\title{
Broyler Tavuklarda Mersin, Biberiye ve Kekik Esansiyel Yağlarının Bağırsak Motilitesi Üzerine Etkisi ${ }^{\#}$
}

\author{
Tuba BÜLBÜL ${ }^{*}$, Vural ÖZDEMİR ${ }^{2}$, Elmas ULUTAŞ³, Aziz BÜLBÜL ${ }^{4}$ \\ 1 Afyon Kocatepe Üniversitesi, Veteriner Fakültesi, Hayvan Besleme ve Beslenme Hastalıklar Anabilim Dal, Afyonkarabisar \\ ${ }^{2}$ Afyon Kocatepe Üniversitesi, Veteriner Fakültesi, Anatomi Anabilim Dah, Afyonkarabisar \\ ${ }^{3}$ Yozgat Bozok. Üniversitesi, Sorgun Veteriner Fakültesi, Fizyoloji Anabilim Dal, Yozgat \\ ${ }_{4}^{4}$ Afjon Kocatepe Üniversitesi, Veteriner Fakültesi, Fisyoloji Anabilim Dal, Afyonkarahisar
}

\#Afjon Kocatepe Üniversitesi Bilimsel Araștirma Projeleri Koordinasyon Birimi tarafindan desteklenmisstir.(Proje no:16.VF.10). \#Bu çalısmanm bir kıımı, Dünya Bilimsel Tavukculuk Derneği Türkije Subesi Uluslararası Kanatl Kongresinde

(9-12 Mayıs 2018, Niğde, Türkiye) sunulmustur.

*Corresponding author e-mail: tbulbul@aku.edu.tr

\section{ÖZ}

$\mathrm{Bu}$ araștırma, broyler beslemede yem katkı maddesi olarak yaygın kullanılmaya başlayan mersin, biberiye ve kekik esansiyel yağlarının ince bağırsak kasılımları üzerine etkisini belirlemek amacıyla yapıldı. Özel bir kanatlı mezbahanesinde elde edilen (40-42 günlük) 10 adet ince bağırsak, krebs solüsyonu $\left(\mathrm{NaCl}, 118 \mathrm{mmol} / \mathrm{l} ; \mathrm{KCl}, 4.7 \mathrm{mmol} / \mathrm{l} ; \mathrm{CaCl}_{2}, 2.5 \mathrm{mmol} / \mathrm{l} ; \mathrm{MgSO}_{4}, 1 \mathrm{mmol} / \mathrm{l} ; \mathrm{KH}_{2} \mathrm{PO}_{4}, 1 \mathrm{mmol} / 1\right.$ glukoz 11 , $\left.\mathrm{mmol} / \mathrm{l} ; \mathrm{NaHCO}_{3}, 25 \mathrm{mmol} / \mathrm{l}\right)$ ile $+4{ }^{0} \mathrm{C}$ 'de laboratuara getirildi. Duodenum, jejenum ve ileum dokuları, $39{ }^{\circ} \mathrm{C}$ sicaklıkta ve $\% 95 \mathrm{O}_{2}-$ $\% 5 \mathrm{CO}_{2}$ gaz karışımı ile sürekli havalandırılan $20 \mathrm{ml}$ krebs çözeltisi içerisinde olacak şekilde dört kadehli izole organ banyosuna yerleştirildi. Dokuların kasılımları "force transducer" ve "acquisition system" yardımı ile bilgisayarda görüntülenerek kaydedildi. Clevenger cihazın hidrodistilasyon metodu ile elde edilen mersin, biberiye ve kekik esansiyel yağları $0,1-1000 \mu \mathrm{g} / \mathrm{ml}$ derișim aralığında duodenum, jejenum ve ileum dokularına uygulanarak etkileri ve etkili dozları belirlendi. Aynı şekilde aynı dokularda asetilkolinin 10-10 $10^{-3} \mathrm{M}$ aralığı ile EFS (Electrical field stimulation; Elektriksel alam uyarımı) uygulanarak maksimal kasılımlar elde edildi. Üç yağında etkili dozları maksimal kasılımların elde edildiği asetilkolin ve EFS ile tekrar değerlendirildi. Her üç dokuda da biberiye ve kekik esansiyel yağlarının $1000 \mu \mathrm{g} / \mathrm{ml}$, mersin yağının ise $300 \mathrm{ve} 1000 \mu \mathrm{g} / \mathrm{ml}$ düzeylerinin spontan kasılımları tamamen engellediği diğer derişimlerin dokular üzerinde belirgin bir yanıt oluşturmadığı görüldü. Asetilkolin ve EFS ile uyarılmış dokularda ise esansiyel yağların etkili dozlarının kasılımları \%15-35 aralığında engellediği ortaya konuldu. Sonuç olarak mersin, biberye ve kekik esansiyel yağlarının ince bağırsak kasılımlarını engellediği in vitro olarak gösterildi. Ancak bu etkinin olușması için yüksek dozlarda uygulanması gerektiği ifade edilebilir.

Anahtar kelimeler: Mersin, biberiye, kekik, esansiyel yăg, ince bağırsak

\section{The Effect of Essential Oils of Myrtle, Rosemary, and Thyme on Intestinal Motility in Broiler}

\begin{abstract}
This research was conducted to determine the effects of essential oils of myrtle, rosemary, and thyme, which are common essential oils in broiler nutrition, on small intestine contractility. For this purpose, small intestines of 10 broiler chickens of 40-42 days old, which were sacrificed in a special slaughterhouse and were put into Krebs solution $(\mathrm{NaCl}, 118 \mathrm{mmol} / \mathrm{l} ; \mathrm{KCl}, 4.7 \mathrm{mmol} / \mathrm{l} ; \mathrm{CaCl} 2,2.5 \mathrm{mmol} / 1$; $\mathrm{MgSO}_{4}, 1 \mathrm{mmol} / \mathrm{l} ; \mathrm{KH}_{2} \mathrm{PO}_{4}, 1 \mathrm{mmol} / 1$ glucose $11, \mathrm{mmol} / \mathrm{l} ; \mathrm{NaHCO}_{3}, 25 \mathrm{mmol} / \mathrm{l}$ ) and transferred to the laboratories at $+4{ }^{\circ} \mathrm{C}$. Isolated strips of duodenum, jejunum and ileum were placed in a four-channeled, isolated organ bath system at $39{ }^{\circ} \mathrm{C}$, ventilated by a mixture of 95\% O $2-\% 5 \mathrm{CO}_{2}$ regularly. The contractions of the tissues were recorded by displaying them on the computer with the help of "force transducer" and "acquisition system". The effective doses and effects of essential oils of myrtle, rosemary, and thyme, obtained by hydrodistillation method of Clevenger apparatus, were determined in a concentration range of 0.1-1000 $\mu \mathrm{g} / \mathrm{ml}$. Similarly, maximal contractions were obtained by applying EFS at acetylcholine concentrations in a range of $10^{-10}-10^{-3} \mathrm{M}$. The maximal effective doses of all three essentil oils were re-evaluated at acetylcholine and EFS applications in which maximal contractions are obtained. It was determined that the essential oils of $1000 \mu \mathrm{g} / \mathrm{ml}$ of rosemary and thyme, and 300 and $1000 \mu \mathrm{g} / \mathrm{ml}$ levels of myrtle inhibited spontaneous contractions of all three tissues completely, whereas no significant responses were observed in these tissues at other concentration levels. In tissues stimulated by acetylcholine and EFS, the effective doses of the essential oils inhibited contractions in the range of $15-35 \%$. In conclusion, the essential oils of myrtle, rosemary, and thyme were demonstrated to inhibit the contractions of small intestine in vitro . However, it has been observed that higher doses are needed to be applied to obtain this effect.

Keywords: Myrtle, rosemary, thyme, essential oils, small intestines
\end{abstract}




\section{GİRİ̧̧}

Esansiyel yağlar; bitkilerin yaprak, çiçek, kabuk, tohum ve köklerinden elde edilen genellikle s1v1 formda ve kolay kristalleşebilen; renksiz veya açık sarı renkte yağımsı karışımlardır. Bulundukları bitkiye özgü, koku ve yakıcı lezzete sahip olup oda sıcaklığında uçucu ve kokulu olmaları en belirgin özelliklerindendir (Sevinç ve Merdun 1995). Suda çözünmeyip, organik çözücülerde çözündükleri için yağ olarak tanımlansalar da sabit yağlardan farklı yapıdadırlar (Bayaz 2014). İçerdikleri etken maddelere göre esansiyel yağların antimikrobiyal, antioksidan, sedatif ve diüretik etkileri bulunmakla beraber (Javanmardi ve ark. 2003) son zamanlarda kanatlı beslemede özellikle sindirimi uyarıcı ve iştah açıcı amaçla da kullanılmaya başlanmıştır (Hernandez 2004).

Esansiyel yağların kanatlı beslemede lezzet üzerine etkisi önem arz etmektedir (Bugdayc1 2008). Deyoe ve ark. (1962), tavukların tat tercihlerini belirlemek amacıyla yaptıkları bir çalışmada içme suyuna ilave edilen tereyağı aroması ve tereyağı ile birlikte melas, portakal, ayva, çikolata, soğan ve hindistan cevizi aromalarının, aroma ilavesi yapılmayan suya göre daha çok tüketildiğini bildirmişlerdir. Aynı zamanda esansiyel yağlarda bulunan eugenol ve nerolinin tavuklar tarafindan istekle tüketilmediğ bu yüzden yem tüketiminin buna bağlı azalabileceği bildirilmektedir. Baharat ve bitkilerden elde edilen esansiyel yağlar, besin maddelerinin sindiriminde etkili olurken (Pradeep ve ark. 1991, Pradeep ve Geervani 1994), baziları safra tuzu sekresyonu üzerine etkili olmaktadır (Bhat ve ark. 1984, Bhat ve Chandrasekhara 1987, Sambaiah ve Srinivasan 1991). Bitki ekstraktlarının broylerlerde besi performans1 ve sindirilebilirlik üzerine etkilerinin incelendiği çalışmada rasyonlara $200 \mathrm{mg} / \mathrm{kg}$ esansiyel yă̆ ekstrakt1-1 (oregano, tarçın ve biber) ve $5000 \mathrm{mg} / \mathrm{kg}$ esansiyel yağ ekstrakt1-2 (adaçay1, kekik ve biberiye) ilave edilmesinin besin maddelerinin sindirilebilirliğini artırdığı bildirilmiştir (Hernandez ve ark. 2004). Kreydiyyeh ve ark. (2000) ise karanfil esansiyel yağında bulunan cinnemaldehyde ve eugenol'ün sirası ile 1000 ve $850 \mathrm{mg} / \mathrm{kg}$ düzeylerinde siçan jejunumda aleninin emilimini azalttığını ortaya koymuşlardır. Buna karşın broylerlerde $100 \mathrm{mg} / \mathrm{kg}$ timol, $100 \mathrm{mg} / \mathrm{kg}$ cinnamaldehyde ve $100 \mathrm{mg} / \mathrm{kg}$ ticari bir esansiyel yağ karışımının 21. ve 40. günlerde pankreas enzimlerinden amilaz, lipaz, tripsin ve kimotripsin enzim etkinliklerini değiştirmediği saptanmıştır (Lee ve ark. 2003).

Bitkisel ekstrakların ve yağların, düz kas kasılımları üzerine farklı etkileri bulunmaktadir. Kemirgenlerde Pavetta crassipes bitkisinin yapraklarından elde edilen ve içeriğinde bol miktarda flavonoidler, tanenler içeren ekstraktın bağırsak ve uterus düz kaslarının spontan kasılımlar üzerinde derişime bağlı olarak önleyici etki yaptığı belirtilmiştir. Etkisini kalsiyum kanalları boyunca oluşturduğu sonucuna varılmıştır. (Amos ve ark. 1998). Aynı şekilde Neorautanenia mitis bitkisinin ekstraktın izole rat uterusun normal ritmik kasılmalarını ortadan kaldırdığı ve ayrıca oksitosinle oluşturulan kasılmaları engellediği belirtilmiştir (Vongtau ve ark. 2000), Onobrychis viciifolia ekstraktının ise ince bağırsak kasılımlarını engellediği gösterilmiştir (İnce ve Filazi 2009). Tersine Indigofera dendroides bitkisinin ise kolinerjik yoldan kasılımı artırdığı belirlenmiştir (Amos ve ark. 2003).

Son y1llarda kanatlı beslemede esansiyel (mersin, biberiye, kekik) yağlar yaygın kullanılmasına karşın ince bağırsak kasılımları üzerine etkileri bilinmemektedir. Bu amaçla bu çalışmada mersin, biberiye ve kekik esansiyel yağlarının tavuk ince bağırsağında kasılımlar üzerine etkisinin belirlenmesi amaçlanmıştır.

\section{MATERYAL ve METOT}

\section{Araştırmada kullanılan esansiyel yağlar}

Mersin, biberiye ve kekik esansiyel yağlar Clevenger cihazın hidrodistilasyon metodu ile elde edilmiştir.

\section{Mersin, biberiye ve kekik esansiyel yağlarının ince bağırsak (duodenum, jejenum ve ileum) kasılımlarına etkisinin belirlenmesi}

Araştırmada özel bir kanatlı mezbahanesinde elde edilen (40-42 günlük) 10 adet ince bağırsak hemen krebs solüsyonuna $(\mathrm{NaCl} \mathrm{118;} \mathrm{KCl} 4,7$; $\mathrm{CaCl} 2$ 2,5; MgSO4 1, KH2PO4 1, NaHCO3 25 ve glikoz 11 $\mathrm{mM}$ ) alınarak $+4{ }^{0} \mathrm{C}^{\prime}$ de fizyoloji $\mathrm{AD}$ laboratuarına getirildi. Takibinde her bir bağırsak bölümü krebs çözeltisi içerisine etrafındaki mezenter ve yağ dokudan dikkatli bir şekilde temizlenerek 0,1 -- 0,3 $\mathrm{cm} \times 0,6 \mathrm{~cm}$ boyutlarında şerit şeklinde doku parçası elde edilmiştir. Hazırlanan bu preparatlar, $39{ }^{\circ} \mathrm{C}$ sicaklikta ve \%95 $\mathrm{O}_{2}-\% 5 \mathrm{CO}_{2}$ gaz karışımı ile sürekli havalandırılan $20 \mathrm{ml}$ krebs çözeltisi içerisinde olacak şekilde izole organ banyosunun I, II, III ve IV numaralı olmak üzere her dört kadehindeki platin halka elektrotun alt ucuna bağlanarak dokunun halka elektrotlar arasında kalması sağlandı. Dokunun diğer ucu üst uçlarından force transducer'a bağlanıp tespit edilecek ve izometrik düz kas hareketleri "force transducer" ve "acquisition system" yardımı ile bilgisayarda görüntülenerek kaydedildi (Bulbul ve ark. 2007). 
Duodenum, jejunum ve ileum üzerine ekstraktın etkisinin tek başına belirlenmesi

Dokular organ banyosunda dengelendikten sonra esansiyel yağlar $0,1-1000 \mu \mathrm{g} / \mathrm{ml}$ derişim aralığında ve her bir doz aralı̆̆ 3 dakika olacak şekilde kümülatif olarak duodenum, jejenum ve ileum dokusuna ayr1 ayr1 uyguland1. Dokular 15 dakika arayla 3 defa yıkanması koşuluyla belirtilen her bir derişim bireysel olarak duodenum, jejenum ve ileum dokusuna ayrı ayrı uygulandı (Bulbul ve ark. 2007).

Duodenum, jejenum ve ileum üzerine asetilkolinin etkisinin belirlenmesi

Dokuların organ banyosuna alışmaları için bir saat beklendikten sonra asetilkolinin $10^{-10}, 3 \times 10^{-10}, 10^{-9}$, $3 \times 10^{-9}, 10^{-8}, 3 \times 10^{-8}, 10^{-7}, 3 \times 10^{-7}, 10^{-6}, 3 \times 10^{-6}, 10^{-5}$, $3 \times 10^{-5}, 10^{-4}, 3 \times 10^{-4}$ ve $10^{-3} \mathrm{M}$ dozlar1 sirasiyla kumulatif biçimde duodenum, jejenum ve ileum dokularına ayr1 ayrı uygulandı. Uygulanan asetilkolin dozlarına cevap gözlemlendikten sonra iki dakika arayla iki kez yıkandı ve 10 dakika da bekletilerek doku dinlendirildi. Her doz icin $\mu \mathrm{g}$ cinsinden elde edilen yanttlar kaydedildi ve bunlardan ortalamalar hesaplandi.

Duodenum, jejenum ve ileum üzerine esansiyel yağların etkisinin asetilkolinle birlikte araştırılması

Dokular organ banyosunda dengelendikten sonra asetilkolinin üç dokuda da maksimal kasılım oluşturan dozu ile yağ ekstrakları beraber uygulandi. Elde edilen yanıtların $\%$ değerleri hesapland.

Duodenum, jejunumu ve ileumu üzerine esansiyel yağların elektriksel alan uyarımı (EFS) ile etkisinin belirlenmesi

Dokular organ banyosunda dengelendikten sonra EFS ile her iki doku için submaksimal kasilımın sağlandığ1 voltaj, frekans ve uyarı derinliği değerleri tespit edilecektir. Bunun için dokuya çeşitli düzeylerde elektrik akımı (10, 20, 30, 40 volt) farklı sürelerde $(0,25,0,5,1 \mathrm{~ms})$ ve siklikta (frekans) $(2,4$, 8, 16, 32, $64 \mathrm{~Hz}$ ) uygulandı (Bulbul ve ark. 2007). En iyi kasilımın meydana geldiği ortalama frekans değeri, uyarı derinliği ve voltaj yüksekliğinde esansiyel yağlarla kasılım yanıtlarının \% değerleri tespit edildi.

İzole organ banyosu değerlendirmelerinde uygulamalar arasında fark olup olmadığının belirlenmesinde Tek Yönlü Varyans Analizi, farkın hangi gruplar arasında olduğunu belirlemek için ise Tukey testi yapıldı (SPSS 13.0). $\mathrm{P}<0.05$ değeri istatistiki açıdan önem sınırı kabul edildi.

\section{BULGULAR}

Duodenum, jejenum ve ileum kasilımları üzerine mersin, biberiye ve kekik esansiyel yağlarının etkisi

Esansiyel yağların $0,1,0,3,1,3,10,100,300$ ve $1000 \mu \mathrm{g} / \mathrm{ml}$ derişimlerde kümülatif uygulaması sonucunda duodenum, jejenum ve ileumda farklı derişimlerde kademeli derişim-yanıtına uygun olmayan gevşemelere sebep olduğu görüldü. Biberiye ve kekik esansiyel yağlarının dokularda $0,1-1000 \mu \mathrm{g} / \mathrm{ml}$ derişimlerinin kümülatif ve bireysel olarak uygulanmasında $1000 \mu \mathrm{g} / \mathrm{ml}$, mersin yağının ise 300 ve $1000 \mu \mathrm{g} / \mathrm{ml}$ dıșındaki derișimlerinin dokular üzerinde belirgin bir yanıt oluşturmadığı, belirtilen derişimlerin uygulanmas1 sonucunda dokulardaki normal (fazik) kontraksiyonların engellendiği görülmüsstür. Buna karşın, yıkama işleminden sonra kasılımların tekrar başladığı belirlendi.

Duodenum, jejenum ve ileum kasilımları üzerine asetilkolinin etkisi

Duodenum, jejenum ve ileum dokuları üzerine uygulanan çeşitli konsantrasyonlardaki asetilkoline $\left(10^{-10}, 3 \times 10^{-10}, 10^{-9}, 3 \times 10^{-9}, 10^{-8}, 3 \times 10^{-8}, 10^{-7}, 3 \times 10^{-7}\right.$, $10^{-6}, 3 \times 10^{-6}, 10^{-5}, 3 \times 10^{-5}, 10^{-4}, 3 \times 10^{-4}$ ve $\left.10^{-3} \mathrm{M}\right)$ ait amplitut değerleri Çizelge 1'de ve bu kasillmlara ait doz-cevap eğrileri ise sırasıyla Şekil 1, 2 ve.3' de gösterildi.

Buna göre her üç dokuda da asetilkolinin konsantrasyon artışına bağlı olarak amplitutlerde büyüme meydana geldiği gözlemlendi. Duodenum ve ileumda $3 \times 10^{-4} \mathrm{M}$, jejenumda ise $10^{-4}$ asetilkolin dozuna alınan cevabın bir önceki cevaba oranla düştüğu gözlemlendiğinden esansiyel yağlarla olan denemelerde, maksimal kasilımı sağlayan etkili asetilkolin dozu olarak duodenum ve ileum için 10${ }^{4}$, jejenum için $3 \times 10^{-5} \mathrm{M}$ konsantrasyon seçildi.

Duodenum, jejenum ve ileum kasilımları üzerine mersin, biberiye ve kekik esansiyel yağlarının etkisinin araştırılması

Mersin, biberiye ve kekik esansiyel yağlarının asetilkolin ile uyarılmış dokularda oluşturduğu inhibisyon Çizelge 2' de gösterilmiştir. Buna göre esansiyel yağların duedenum, jejenum ve ileum düz kaslarında ACh tarafindan oluşturulan maksimal kasılımda \%14-43 aralığında inhibisyon oluşturduğu buna karşın kasilımları tamamen inhibe etmediği görüldü.

Duodenum, jejunum ve ileum üzerine esansiyel yağların EFS ile etkisinin belirlenmesi

Mersin, biberiye ve kekik esansiyel yağlarının EFS ile uyarılmış dokularda oluşturduğu inhibisyon çizelge 3' de gösterildi. Elektriksel alan uyarımı ile 
duedenum, jejenum ve ileum düz kaslarında oluşturulan maksimal kasılımda \%9-25 aralığında inhibisyon görüldü. Buna karşın esansiyel yağların
EFS ile oluşturulan maksimal kasılımları tamamen inhibe etmediği belirlendi.

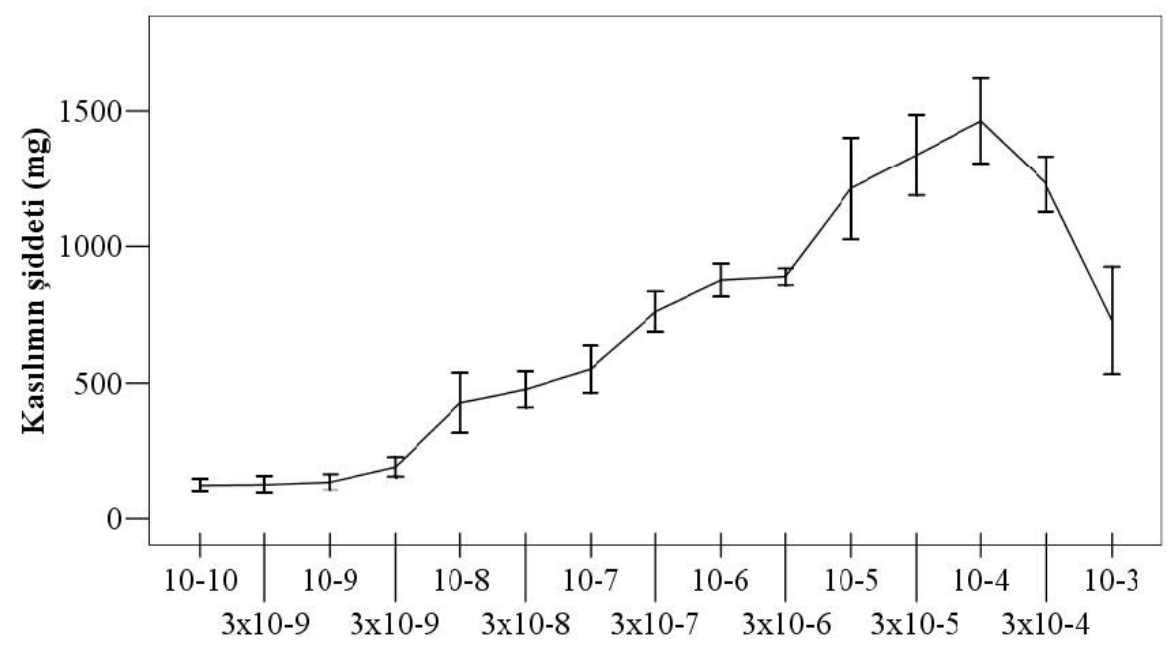

Şekil 1. Duodenum düz kasında asetilkolinin doz cevap eğrisi

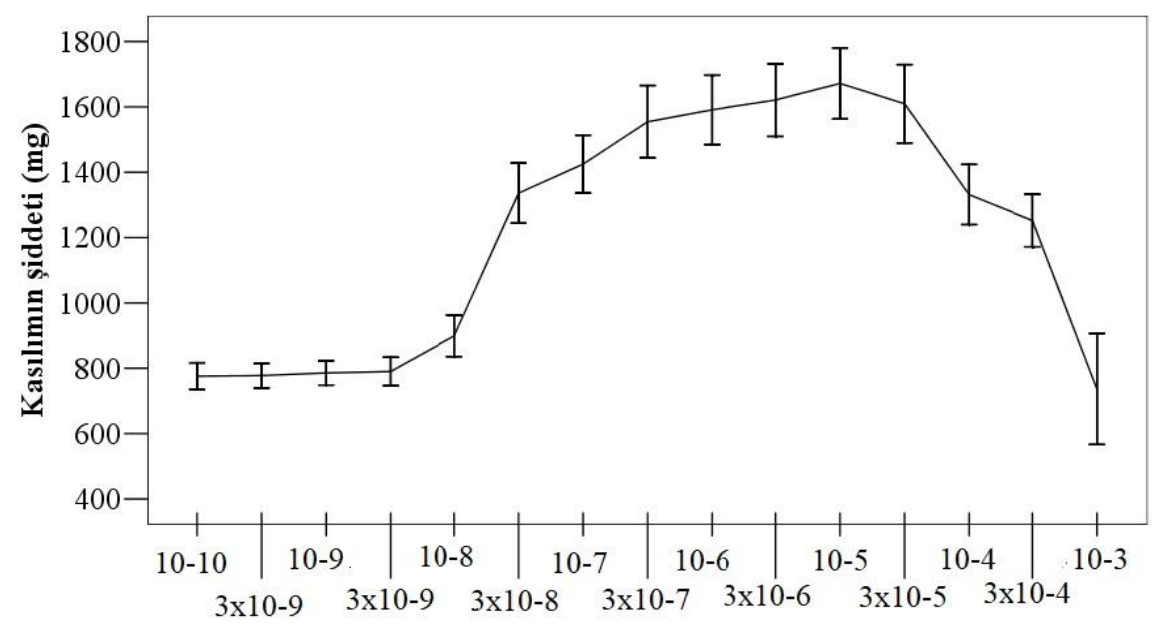

Şekil 2. Jejenum düz kasında asetilkolinin doz cevap eğrisi

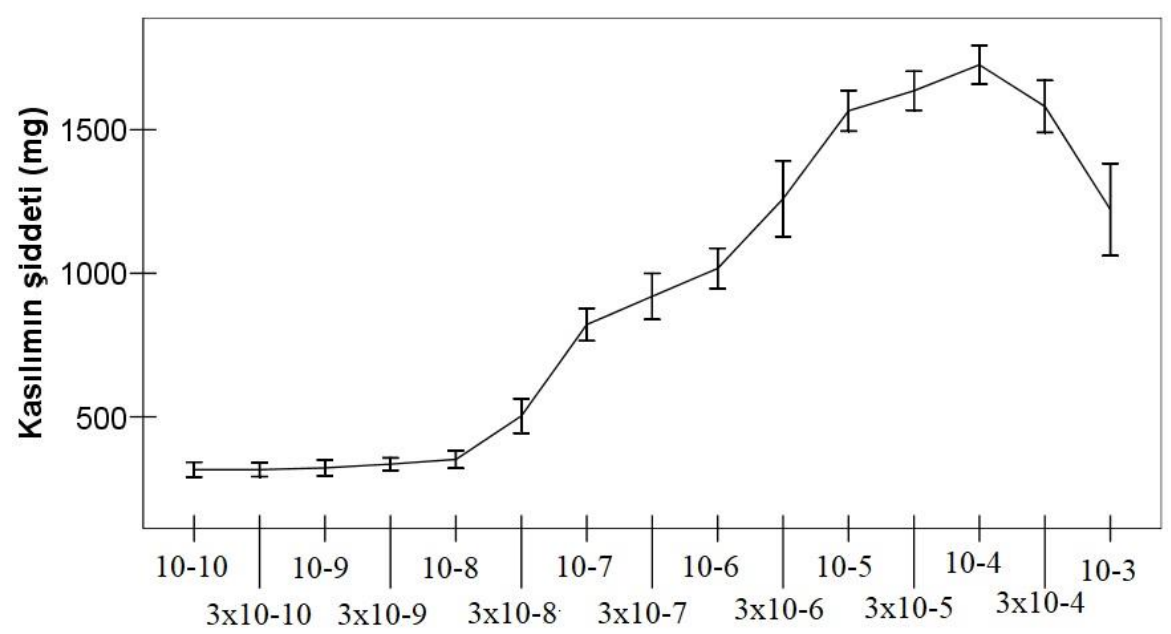

Şekil 3. İleum düz kasında asetilkolinin doz cevap eğrisi 
Çizelge 1. Duodenum, jejenum ve ileum düz kasları üzerine kümülatif olmayan asetilkolin uygulamasıyla elde edilen ortalama kasılım (mg) değerleri $(n=6)$

\begin{tabular}{cccc}
\hline & & Kasilım (mg) & \\
\hline Konsantrasyon (M) & Duedenum & Jejenum & İleum \\
\hline Ach $10^{-10} \mathrm{M}$ & $94 \pm 23,44$ & $689 \pm 49,65$ & $281 \pm 32,13$ \\
Ach $3 \times 10^{-10} \mathrm{M}$ & $88 \pm 31,07$ & $701 \pm 46,41$ & $279 \pm 29,56$ \\
Ach $10^{-9} \mathrm{M}$ & $98 \pm 28,41$ & $712 \pm 45,41$ & $288 \pm 33,95$ \\
Ach $3 \times 10^{-9} \mathrm{M}$ & $132 \pm 33,73$ & $703 \pm 53,41$ & $310 \pm 26,67$ \\
Ach $10^{-8} \mathrm{M}$ & $234 \pm 104,58$ & $803 \pm 77,96$ & $302 \pm 37,53$ \\
Ach $3 \times 10^{-8} \mathrm{M}$ & $381 \pm 62,61$ & $1198 \pm 112,44$ & $412 \pm 73,27$ \\
Ach $10^{-7} \mathrm{M}$ & $432 \pm 82,05$ & $1298 \pm 108,39$ & $721 \pm 69,45$ \\
Ach $3 \times 10^{-7} \mathrm{M}$ & $698 \pm 70,45$ & $1384 \pm 135,67$ & $800 \pm 98,28$ \\
Ach $10^{-6} \mathrm{M}$ & $765 \pm 57,61$ & $1432 \pm 130,31$ & $912 \pm 85,85$ \\
Ach $3 \times 10^{-6} \mathrm{M}$ & $857 \pm 28,77$ & $1456 \pm 135,70$ & $1012 \pm 161,64$ \\
Ach $10^{-5} \mathrm{M}$ & $987 \pm 178,93$ & $1540 \pm 133,27$ & $1456 \pm 86,79$ \\
Ach $3 \times 10^{-5} \mathrm{M}$ & 1141,83 & $1432 \pm 146,78$ & $1554 \pm 82,98$ \\
Ach $10^{-4} \mathrm{M}$ & $1234 \pm 150,56$ & $1130 \pm 112,68$ & $1613 \pm 83,03$ \\
Ach $3 \times 10^{-4} \mathrm{M}$ & $1131 \pm 97,60$ & $1076 \pm 98,42$ & $1413 \pm 110,82$ \\
Ach $10^{-3} \mathrm{M}$ & $456 \pm 187,23$ & $378 \pm 208,26$ & $913 \pm 196,47$ \\
\hline
\end{tabular}

Çizelge 2. Esasniyel yağların Ach ile uyarılmiş dokularda oluşturduğu \% inhibisyon

\begin{tabular}{ccccc}
\hline Dokular & Mersin & Mersin & Biberiye & Kekik \\
& $300 \mu \mathrm{g}$ & $1000 \mu \mathrm{g}$ & $1000 \mu \mathrm{g}$ & $1000 \mu \mathrm{g}$ \\
\hline Duodenum & $14,80 \pm 0,38$ & $36.41 \pm 0.34$ & $35,47 \pm 1,98$ & $18,88 \pm 1,23$ \\
Jejenum & $19,63 \pm 1.38$ & $42,47 \pm 2,03$ & $30,87 \pm 1,11$ & $17,67 \pm 1,05$ \\
İleum & $14,93 \pm 1.42$ & $38,44 \pm 2.28$ & $32,46 \pm 1,54$ & $21,19 \pm 1,33$ \\
\hline
\end{tabular}

*Asetilkolin duodenum ve ileumda $10^{-4}$, ileumda $10^{-5} \mathrm{M}$ uygulanmıştır

Çizelge 3. Esansiyel yağların EFS ile uyarılmış dokularda oluşturduğu \% inhibisyon

\begin{tabular}{ccccc}
\hline Dokular & Mersin & Mersin & Biberiye & Kekik \\
& $300 \mu \mathrm{g}$ & $1000 \mu \mathrm{g}$ & $1000 \mu \mathrm{g}$ & $1000 \mu \mathrm{g}$ \\
\hline Duodenum & $8.80 \pm 0,44$ & $15.58 \pm 0,48$ & $13,47 \pm 1,08$ & $17,14 \pm 0,38$ \\
Jejenum & $13,53 \pm 1.18$ & $16,13 \pm 0,43$ & $16,87 \pm 1,01$ & $22,09 \pm 1,05$ \\
İleum & $9,93 \pm 0,78$ & $17,89 \pm 1.02$ & $24,64 \pm 1,05$ & $14,09 \pm 0,36$ \\
\hline
\end{tabular}

* Her üç doku içinde 20 volt $0,5 \mathrm{~ms}$ ve $32,64 \mathrm{~Hz}$ elektrik uygulandı

\section{TARTIŞMA}

Son y1llarda kanatlı beslemede esansiyel yağlar, birçok fonksiyonun yanı sindirim düzenleyicisi olarak kullanılmaya başlanmışırı. Yapılan çalışmalarda esansiyel yağların besin maddelerinin sindiriminde görevli enzimler üzerine etkili olabileceği ifade edilmiştir (Bhat ve ark., 1984; Bhat ve Chandrasekhara, 1987; Sambaiah ve Srinivasan, 1991). Günümüzde esansiyel yağların mide bağırsak sistemi kasilımlarını düzenleyerek de sindirime yardımcı olabileceği ifade edilmektedir. Nitekim 
kemirgenlerde Pycnocycla caespitosa (Sadraei ve ark., 2016) Benium persicum (Ghader ve ark., 2011), Pterodon polygalaeflorus (Leonhardt ve ark., 2010), Chrysactinia Mexicana (Daniel ve ark., 2016), Teucrium polium (Sadraei ve ark., 2001) ve koyunda Mentha longifolia (Ghader ve ark., 2012) bitkilerinden elde edilen esansiyel yağların ratlarda mide bağırsak sisteminde kasılımları engellediği gösterilmiştir. Yukarıda bildirilen yağlar dışında yağların içeriğinde bulunan terpenlerin ve fenolik bileşiklerin de kasılımların üzerine etkileri incelenmiştir. Terpenlerden $\beta$-caryopyllene (Sadraei ve ark., 2003), 1.8-sineol (Pinto ve ark., 2009) ve Eucalyptol'ün (Ponce-Monter ve ark., 2008) düz kas kasılımlarını engellediği gösterilmiştir. Benzer şekilde 1,8-sineol'un trakeal düz kaslarda $\mathrm{K}$ ile uyarılmış kasılmaları azalttığı, casimiroa pringlei uçucu yağının temel bileşenlerinden olan saf ticari piperiton, ökaliptol ve alfa-terpineolün ise sıçan uterusu üzerinde spazm çözücü bir etkiye neden olduğu gösterilmiştir (Ribeiro ve ark., 2010). Flavonoidler fenolik bileşiktir ve bağırsak peristaltizmine etkileri vardır (Di Carlo ve ark., 1993). Genistein ve kersetin gibi flavonoidler, tavşan duodenumunun düz kasında spontan kasılmaların genliğini azalttığı, ancak sıklığını değiştirmedi belirlenmiştir. Genistein etkisine kalsiyum ve potasyum kanalları aracilık ederken, quercetinin etkisinin cAMP ve protein kinaz A'dan kaynaklandığ1 gösterilmiştir (Santos-Fagundes ve ark., 2015).

Bu çalışmada, biberiye ve kekik esansiyel yağlarının dokularda $1000 \mu \mathrm{g} / \mathrm{ml}$, mersin yağının 300 ve 1000 $\mu \mathrm{g} / \mathrm{ml}$ dozlarında her üç dokuda (duodenum, jejenum ve ileum) normal (fazik) kasilımları tamamiyle engellerken, diğer dozların etkisiz olduğu görülmüştür. Buna karşın kasıllımları engelleyen dozların mersin için yüksek, kekik ve biberiye için ise çok yüksek dozlarda olduğu görüldü.

Asetilkolinin, mide bağırsak sisteminde parasempatik innervasyonun önemli bir sinirsel aracısı olup muskarinik reseptörleri uyararak düz kas kasılımına neden olduğu bilinmektedir. Midebağırsak kanalı düz kaslarında muskarinik reseptörlerin M1, M2, M3, M4 ve M5 olmak üzere 5 alt tipi bulunmaktadır (Giraldo ve ark., 1987; 1988; Iino ve ark. 2004). M2 (\%70-80) ve M3 (\%20-30) reseptörler ince bağırsaktaki düz kas hücre membranında yaygın bir şekilde bulunurken, M1, M5 ve M4 çok daha az yoğunlukta bulunmaktadır (Iino ve ark. 2004). M1, M3, M5 reseptörlerinin aktivasyonu fosfoinozitit hidrolizi ve kalsiyum salınımı aracilığıyla görev yaparken, M2 ve M4 reseptörlerinin aktivasyonu sAMP birikimini engelleyerek görev yapmaktadır. M2 reseptörlerinin sAMP seviyeleri üzerindeki inhibitor etkisi bu reseptörlerin dolaylı rolünü ortaya koymaktadır
(Ehlert ve ark., 1999a, 1999b). Aynı zamanda kobay ileumunda M2 reseptörlerinin, zar depolarizasyonu icin katyonik kanalların açılmasında önemli bir role sahip olduğu bildirilmektedir (Zholos ve Bolton, 1997). Valentino ve ark. (1979)'nın izole kobay ileumunda yaptıkları çalışmada etkili doz olarak $5 \times 10^{-6} \mathrm{M}$ dozunu kullanmaları, Korczynski ve ark. (2006)'nın ise rat jejunumunda yaptıkları çalı̧mada etkili doz olarak $10^{-5} \mathrm{M}$ dozunu kullanmaları farklı hayvan türlerinde muskarinik reseptör dağılımı ve yoğunluğunun farklı olduğunu akla getirmektedir. $\mathrm{Bu}$ çalışmada, her üç dokuda da asetilkolinin konsantrasyon artışına bağlı olarak amplitutlerde büyüme meydana geldiği gözlemlendi. Duodenum ve ileumda, $3 \times 10^{-4} \mathrm{M}$, jejenumda ise $10^{-4}$ asetilkolin dozuna alınan cevabın bir önceki cevaba oranla düştügü gözlemlendiğinden esansiyel yağlarla olan denemelerde, maksimal kasılımı sağlayan etkili asetilkolin dozu olarak duodenum ve ileum için 10${ }^{4}$, jejenum için $3 \times 10^{-5} \mathrm{M}$ konsantrasyon seçildi. Bu bağlamda aynı hayvan türünde farklı dokularda (duedenum, jejenum ve ileum) asetil kolinin doz farklılığının reseptör dağılımındaki farklilıktan kaynaklandığ1 düşünülmektedir.

Elektriksel alan uyarımı ince bağırsaklarda bifazik kasılımları nöranal olarak uyarmaktadır (Sadraei ve ark., 2013). Aynı zamanda kasılımın oluşmasında adrenerjik ve kolinerijk olmayan sinirlerden salınan nörotransmiter maddelerin aracilık ettiği bildirilmektedir (Ekblad ve Sundler 1993). Bu çalışmada bildirimlere uygun olarak üç dokudada maksimal kasilımlar 20 volt $0,5 \mathrm{~ms}$ ve $32,64 \mathrm{~Hz}$ EFS uygulaması ile elde edilmiştir.

$\mathrm{Bu}$ çalışmada her üç esansiyel yağda $300 \mu \mathrm{g} / \mathrm{ml}$ veya üzeri düzeylerde spontan kasılımları tamamen inhibe ederken asetilkolin veya EFS ile uyarilmış dokularda kasılımları tamamen engellemediği buna karşıllık kasıllımın şiddetini azalttığı görülmüş̧ür. Bu bağlamda asetailkolinin muskaranik reseptörler üzerinden EFS'nin ise ise NANC sinirlerden salınan nörotransmitterler üzerinden etkinlik gösterdiği düşünüldüğü zaman; mersin, biberiye ve kekik esansiyel yağlarının başka bir mekanizma ile ince bağırsak kasılımlarını inhibe ettiği görülmektedir.

\section{SONUÇ}

Mersin, biberiye ve kekik esansiyel yağlarının ince bağırsak kasılımları üzerine $100 \mu \mathrm{g} / \mathrm{ml}$ 'dan düşük düzeylerde etkinlik göstermezken; Mersin için 300 $\mu \mathrm{g} / \mathrm{ml}$, biberiye ve kekik için $1000 \mu \mathrm{g} / \mathrm{ml}$ düzeyinde spontan kasilımlarin tamamen engellendiği belirlenmiştir. Bu etkinin muskaranik reseptörler veya NANC nöratransmiterler üzerinden oluşmadığı anlaşılmış, olasılıkla da 
etkisini kalsiyum kanalları üzerinden göstermiş olabileceği öngörülmüştür. Mersin, biberiye ve kekik esansiyel yağların in vitro kasılımlar üzerine etkinlik gösteren düzeyleri ile kanatlı beslemede kullanılan düzeyleri değerlendirildiğinde bu yağların yem katk1 maddesi olarak rasyona ilave edilen miktarlarının ince bağırsak motilitesi üzerine etkisinin olamayacağ1 düşünülmektedir.

\section{KAYNAKLAR}

Amos S, Okwuasaba FK, Gamaniel K, Akah P, Wambebe C. Inhibitory effects of the aqueous extract of Pavetta crassipes leaves on gastrointestinal and uterine smooth muscle preparations isolated from rabbits, guinea pigs and rats. J. Ethnopharmacol. 1998; 61: 209-213.

Amos S., Binda L, Kunle OF, Okafor I, Emeje M, Akah PA, Wambebe C, Gamaniel K. Smooth muscle contraction induced by Indigofera dendroides leaf extracts may involve calcium mobilization via potential sensitive channels. Phytother. Res. 2003; 17: 792-796.

Bayaz M. Esansiyel yağlar: Antimikrobiyal, Antioksidan ve Antimutajenik Aktiviteleri. Akademik Gida. 2014; 12(3): 45-53

Bhat BG, Chandrasekhara N. Effect of black pepper and piperine on bile secretion and composition in rats. Nahrung. 1987; 31: 913916.

Bhat BG, Srinıvasan MR, Chandrasekhara N. Influence of curcumin and capsaicin on the composition and secretion of bile in rats. J. Food Sci. Tech. 1984; 21: 225-227.

Bugdayc1 KE, Ergün A. Esansiyel yağ ve/veya probiyotiğin broylerlerde performans, immun sistem ve baz1 kan parametreleri üzerine etkisi. Ankara Üniv Vet Fak Derg. 2011; 58: 279-284

Bulbul A, Yağci A, Altunbaş K, Sevimli A, Celik HA, Karadeniz A, Akdağ E. The role of nitric oxide in the effects of ovarian steroids on spontaneous myometrial contractility in rats. Theriogenology. 2007; 68(8): 1156-1168

Daniel ZM, Laura G, Miguel ÁZS, Salud PG, María DM. Antispasmodic effects and action mechanism of essential oil of chrysactinia mexicana a. gray on rabbit Ileum. Molecules. 2016; 21(6):783; doi:10.3390/molecules21060783

Deyoe CW, Davies RE, Krishnan R, Khaund R, Couch J.R. Studies on the taste preference of the chick. Poult. Sci. 1962; 41:
781-784. In: Lee KW, Everts H, Beynen AC. Essential oils in broiler nutrition. Int. J. Poult. Sci. 2004; 3(12): 738-752.

Di Carlo GL, Autore G, Izzo AA, Maiolino P, Mascolo N, Viola $\mathbf{P}$, Diurno MV, Capasso F. Inhibition of intestinal motility and secretion by flavonoids in mice and rats: structure-activity relationships. J Pharm Pharmacol. 1993; 45(12):1054-9.

Ehlert FJ, Sawyer GW, Esqueda EE. Contractile role of M2 and M3 muscarinic receptors in gastrointestinal muscle. Life Sci. 1999; 64 (67): 387-394

Ekblad E, Sundler F. Motor responses in rat ileum evoked by nitric oxide donors vs. field stimulation: Modulation by pituitary adenylate cyclase activating peptide forskolin and guanylate cyclase inhibitors. J Pharmacol Exp Ther. 1997; 283:23-28.

Ghader JA, Massoud M, Bahram DN, Farshad K. Effects of mentha longifolia essential oil on ruminal and abomasal longitudinal smooth muscle in sheep. The Journal of Essential Oil Research. 2012; 24: 61-69

Ghader JA, Massoud M, Bahram DN, Farshad K. Effects of Bunium persicum (Boiss.) Essential Oil on the Contractile Responses of mooth Muscle: an in vitro Study. Veterinary Research Forum. 2011; 2: 87-96

Giraldo E, Monferini E, Ladinsky M, Hammer R. Muscarinic receptor heterogeneity in kobay intestinal smooth muscle: binding studies with AFDX 116. Eur. J. Pharmacol. 1987; 141: 475-477.

Giraldo E, Vigano MA, Hammer R, Ladinsky H. Characterization of muscarinic receptors in kobay ileum longitudinal smooth muscle. Mol. Pharmacol. 1988; 33: 617-625.

Hernandez F, Madrid J, Garcia V, Orengo J, Megias MD. Influence of two plant extracts on broilers performance, digestibility, and digestive organ size. Poult. Sci. 2004; 83: 169 - 174.

Ince S, Filazi A. (2009) Farelerde Korunga Bitkisinin (Onobrychis viciifolia) Bağırsaklara Etkisi. Kafkeas Univ. Vet. Fak. Derg. 2009; 15: 401-406.

Iino S, Ward SM, Sanders KM. Interstitial cells of Cajal are functionally innervated by excitatory motor neurones in the murine intestine. J Physiol. 2004; 556:521-30.

Javanmardi J, Stushnoff C, Lcke E, Vivanco JM. Antioxidant activity and total phenolic 
content of Iranian Acimum Accessions. Food Chemistry. 2003; 83: 547-550.

Korczynskı W, Ceregrzyn M, Kato I, Wolınskı J, Zabielsk1 R. The effect of orexins on intestinal motility in vitro in fed and fasted rats. Journal of Physiology and Pharmacology. 2006; 57(6): 43-54.

Kreydiyyeh SI, Usta J, Copti R. Effect of cinnamon, clove and some of their constituents on the $\mathrm{Na}+-\mathrm{K}+$-ATPase activity and alanine absorption in the rat jejunum. Food Chem. Toxicol. 2000; 38: 755-762.

Lee KW, Everts H, Kappert HJ, Frehner M, Losa R, Beynen AC. Effects of dietary essential oil components on growth performance, digestive enzymes and lipid methabolism in female chickens. Br. Poult. Sci. 2003; 44(3): 450-457.

Leonhardt V, Leal-Cardoso JH, Lahlou S, Albuquerque AA., Porto RS, Celedônio NR, Oliveira AC, Pereira RF, Silva LP, Garcia-Teófilo TM, Silva AP, Magalhães J, Duarte GP, Coelho-De-Souza AN. Antispasmodic effects of essential oil of Pterodon polygalaeflorus and its main constituent $\beta$-caryophyllene on rat isolated ileum. Fundam Clin Pharmacol. 2010; 24(6):749-58. doi: 10.1111/j.14728206.2009.00800.x.

Pinto NV, Assreuy AM, Coelho-De-Souza AN, Ceccatto VM, Magalhães PJ, Lahlou S, Leal-Cardoso JH. Endothelium-dependent vasorelaxant effects of the essential oil from aerial parts of Alpinia zerumbet and its main constituent 1,8-cineole in rats. Phytomedicine. 2009; 16: 1151-1155.

Ponce-Monter H, Pérez S, Pérez C, Zavala M, Oropeza M, Cárdenas N. Campos $M$. Chemical composition and antiespasmodic effect of Casimiroa pringlei essential oil on rat uterus. Fitoterapia. 2008; 79: 446-450.

Pradeep KU, Geervanı P, Eggum BO. Influence of spices on utilization of sorghum and chickpea protein. Plant Food Hum. Nutr. 1991; 41: 269-276.

Pradeep KU, Geervani P. Influence of spices on protein utilization of winged bean (Psophocarpus tetragonolobus) and horsegram (Dolichos biflorus). Plant Food Hum. Nutr. 1994; 46: 187-193.

Ribeiro TP, Porto DL, Menezes CP, Antunes AA, Silva DF, De Sousa DP, Nakao LS, Braga VA, Medeiros IA. Unravelling the cardiovascular effects induced by alpha- terpineol: a role for the nitric oxide-cGMP pathway. Clin Exp Pharmacol Physiol. 2010; 37: 811-6.

Sadraei H, Hajhashemi V, Ghannadi A, Mohseni M. Antispasmodic effect of aerial part of teucrium polium l. essential oil on rat 1solated ileum in vitro. Medical Journal of the Islamic Republic of Iran. 2001; 14: 355358

Sadraei H, Asghari G, Alipour M. Antispasmodic assessment of hydroalcoholic extract and essential oil of aerial part of Pycnocycla caespitosa Boiss.\&Hausskn on rat ileum contractions. Res. Pharm. Sci. 2016; 11: 33-42.

Sadraei H, Asghari G, Emami S. Inhibitory effect of Rosa damascenaMill flower essential oil, geraniol and citronellol on rat ileum contraction. Res Pharm Sci. 2013; 8:17-23

Sadraei H, Ghannadi A, Malekshahi K. Relaxant effect of essential oil of Melissa officinalis and citral on rat ileum contractions. Fitoterapia. 2003; 74: 445- 52

Sambaiah K, Srinivasan K. Secretion and composition of bile in rats fed diets containing spices. J. Food Sci. Tech. 1991; 28: 35-38.

Santos-Fagundes D, Grasa L, Gonzalo S, Valero MS, Castro M, Arruebo MP, Plaza MA, Divina-Murillo M. Different mechanisms of actions of genistein, quercetin on spontaneous contractions of rabbit duodenum. Rev. Esp. Enferm. Dig. 2015; 107: 413-416.

Sevinç A, Merdun B. Türkiyede yetisen uçucu yag içeren bitkiler ve kullanım alanları. Bitirme ödevi, Ankara Üniversitesi Ziraat Fakültesi Gıda Mühendisligi Bölümü. 1995.

Valentino RJ, Smith CB, Woods JH. An unusual benzazocine elicits acetylcholine release in the isolated kobay ileum. Nature. 1979; 281: 370-372.

Vongtau HO, Amos S, Binda L, Kapu SD, Gamaniel KS, Kunle OF, Wambebe C. Pharmacological effects of the aqueous extract of Neorautanenia mitis in rodents. J. Ethnopharmacol. 2000; 72: 207-214.

Zholos AV, Bolton TB. Muscarinic receptor subtypes controlling the cationic current in guinea-pig ileal smooth muscle. Br. J. Pharmacol. 1997; 122: 885-893. 